Article

\title{
Social Finance and Banking Research as a Driver for Sustainable Development: A Bibliometric Analysis
}

\author{
Silvana Secinaro ${ }^{1}$, Davide Calandra ${ }^{1, * \mathbb{C}}$, Denisa Petricean ${ }^{2}$ and Federico Chmet ${ }^{1}$ \\ 1 Department of Management, University of Turin, 10134 Turin, Italy; silvana.secinaro@unito.it (S.S.); \\ federico.chmet@unito.it (F.C.) \\ 2 Department of Economics and Finance, Brunel University London, London UB8 3PH, UK; \\ denisa.petricean@brunel.ac.uk \\ * Correspondence: davide.calandra@unito.it
}

Citation: Secinaro, S.; Calandra, D.; Petricean, D.; Chmet, F. Social

Finance and Banking Research as a Driver for Sustainable Development: A Bibliometric Analysis. Sustainability 2021, 13, 330. https://doi.org/ $10.3390 /$ su13010330

Received: 6 December 2020 Accepted: 29 December 2020 Published: 31 December 2020

Publisher's Note: MDPI stays neutral with regard to jurisdictional clai$\mathrm{ms}$ in published maps and institutional affiliations.

Copyright: (C) 2020 by the authors. Licensee MDPI, Basel, Switzerland. This article is an open access article distributed under the terms and conditions of the Creative Commons Attribution (CC BY) license (https:// creativecommons.org/licenses/by/ $4.0 /)$.

\begin{abstract}
Social finance and banking with an embedded social purpose have been on the rise in recent decades. Social entrepreneurs have repeatedly stressed the critical need for financial support from social banks. This study aims to provide a bibliometric analysis of the status of the field in social finance and banking, recognising main topics from existing research and establishing future re-search challenges. Our study used science mapping workflow and multiple research questions to investigate the broad literature about social banking and finance. With in-depth bibliometric analysis, authors examined qualitative and quantitative variables as primary research infor-mation, relevant sources, subject areas, authors data, social, thematic and intellectual structure. The data was retrieved from Web of Science (WOS) and then analysed using Bibliometrix R-package. The analysis was based on a sample of 270 articles and demonstrates a multidisciplinary vision of the research flow investigated. Our results show several insights regarding journals, authors and geographical interest of this research stream. Specifically, the literature, although dwelling on social finance and banking, includes five theoretical and practical clusters as (1) people's well-being, combined with technological innovation, (2) governance, (3) ethical investment and sustainable development, (4) corporate social responsibility (CSR), and (5) transparency. The authors also note a line of research that observes technological solutions for the response to social and environmental problems. These results may be useful for researchers, practitioners, and policymakers to foster social finance and financial system tools.
\end{abstract}

Keywords: social finance; social banking; sustainable development; bibliometric analysis

\section{Introduction}

Investment of capital for social and financial creation has ancient roots. Cooperatives, religious institutions, credit unions and mutual societies have been managing capitals for the social project for many years back. However, during recent times, new ways of managing finance for achieving positive social impacts have emerged, which have been classified under the term "Social Finance" (SF).

Past literature reviews have defined SF as an alternative financing tool for projects and ventures with financial returns that are also able to generate a positive impact on society, the environment and sustainable development [1-4].

On the same line is the definition of Périlleux [5] who explains SF as the sum of financial institutions, products and practices in which not only the maximisation of profit is sought but also social, ecological or ethical results. Additionally, SF includes initiatives such as savings groups, microfinance and collaborative finance (such as social crowdfunding).

More generally, the term SF indicates different models and approaches, such as crowdfunding, alternative currencies, social investment, microfinance, socially responsible investments, social impact bonds and venture philanthropy [5-8]. Therefore, as suggested 
by the latest results of Rizzi et al. (2018) [9], two forms of SF have emerged, including primarily social impact investment and ethical banking.

Moreover, when talking about SF, it is important to mention "Social Banking" (SB) as well. As is the case for SF, there is not only one correct definition of SB. For many people, SB could sound like an oxymoron, which is to combine two words that do not belong together. To others, SB refers to these institutions directed to charitable clients.

$\mathrm{SB}$ is also associated with governmental institutions, in addition to microfinance. Thus, Frans de Clerck, co-founder of Triodos Belgium and former head of the supervisory board of the Institute for Social Banking, concludes that there is no clear and unique interpretation of $\mathrm{SB}$, as social, alternative, and ethical banks are definitions which refer to methods of giving money. According to the authors, therefore, there is no precise definition of SB as it belongs to different financial traditions [10].

Although De Clerck's definition remains interesting, for this paper, we adopt a more technical explanation. As defined by James Niven, from the Global Alliance for Banking on Values it is possible to actively engage in wide-ranging discussions about the future of the financial sector in order to have a direct impact on organisations which invests in social, environmental, and cultural issues. Hence, in line with Niven's argument, we define $\mathrm{SB}$ as banking where the main purpose is to have a positive impact on people and communities [11].

All these premises give the idea of two parallel research models that overlap in practice but demonstrate the inability of the literature to provide an analysis of the research flow conducted so far. This research gap has recently been highlighted by Rizzi et al. (2018) [9], which in its conclusions calls for the convergence of the two models in order to advance the development of the sector concerning commercial finance. Additionally, also the recent publications highlight the importance of sustainable financing tools for social purposes [12-14].

Therefore, this article proposes a broader investigation that includes the study of the primary bibliometric data [15-20] on peer-reviewed papers listed on the Web of Science (WOS).

The main results denote a multidisciplinary vision of the field of research studied. The literature includes an interesting discussion of the tools of social finance, sustainable development, social responsibility, and human rights challenges. Also, we note a research strand that observes technological solutions for the response to social and environmental problems. Our analysis is innovative for the topic of interest as it applies a methodology not yet used. Moreover, and more importantly, it affirmed that the social and right approach is not only related to the person but also the environment.

Focusing on SF and SB, our paper aims to map, discuss, and critique the research discussion on these topics answering the following questions: (1) what are the main features of these research streams considering authors, citations and geographical interest? (2) What are the most frequent issues and topics of this literature? (3) What are the possible implications for future research in this field?

The rest of the paper is structured as follows. Section 2 defines the current literature and debates why a bibliometric analysis using open coding methods may be useful to reach our research aims. Section 3 establishes the methodology flow. Section 4 shows the results of our research. Section 5 provides an in-depth data interpretation, commenting on and critiquing the main findings. In conclusion, Section 6 concludes this paper considering present implications and suggesting future research paths.

\section{Background}

During the past decades, SF and SB have gained importance and popularity, growing starting to grow significantly and attracting the interest of different stakeholders ranging from governmental agencies to mainstream financial markets. Although the accessible data on SF is limited due to the fragmentation of sectors and investment approaches, the market potential has been estimated to be extremely prosperous. For instance, microfinance, which 
can be considered an earlier example of SF, is estimated to contain over over USD \$50 billion of loans to over 100 million micro-entrepreneurs [21]. Another study conducted by the European Investment Forum outlined that the European SF market showed around USD \$21 billion in 2013 in France, Italy, Germany, the Netherlands and the United Kingdom (UK), representing the leading markets [22].

SF in Europe is developing in different ways and forms, driven by other actors. In the beginning, SF was created to assist social ventures with their financial needs. Even though SF can create both social and financial value, social ventures sometimes face difficulties accessing different financial markets due to their nature and high risk [23-27]. Secondly, most European governments have recognised the potential and possibile of growth of SF. In this case, governments have been sustaining the development of SF through direct and indirect investment or through developing particular policies to facilitate SF markets [28]. Thirdly, SF provides the perfect scenario for the growth and demand of corporate social responsibility (CSR), firms in the financing and banking sector [29]. Lastly, SF attracts socially-minded investors, such as philanthropic organisations, or socially motivated people, who are continuously researching new methods of allocating financial resources to socially motivated firms, to not only returns but also keep their main priority, which is the "bettering of the society" [3,30].

Nevertheless, accessing enough financial resources is highly challenging for social enterprises [31]. As conventional funding in the social sector is scarce and limited to specific projects, they do not allow investment in overheads or product and service development. However, recently social enterprises have been gaining interest from venture capitalists because of their fast growth in terms of generating income [32]. Financial instruments considered in the discussion are mostly private equity, unsecured debt and their hybrids [28]. Notwithstanding, investors do not solely value just financial returns. The concept of impact investing $[33,34]$ refers to proactively perusing social and ecological features together with financial goals. In this investing, the creation of measurable social impact is the primary goal, and financial returns are considered as additional benefits. During the last few years, social impact investing has gained traction in the USA and UK with an increased number of private impact investing funds spread across the globe [35].

The growing interest in the literature and the intersection of SF and SB theories, however, are not accompanied by specific bibliometric studies. For example, recent studies have focused on vertical research flows such as social entrepreneurship [36], the social aspects of Islamic finance [37] and sustainable banking investments [38], leaving aside a relevant research gap in addition to what Rizzi et al. (2018) [9] have pointed out, as well as the social impact outlined in Sustainability journal [12].

\section{Methodology}

To generate a dataset of relevant sources, the authors started with keyword selection as the giant step after research questions were assessed [39]. Our analysis considered "So-cial finance" and "Social Banking" as a research strategy. This strategy allowed us to fo-cus the research inclusively and explore the two research flows [40-42]. Keyword selection was outlined by Chen \& Xiao (2016) [43] in a paper which suggested an analysis from the top-down level, considering macro-field analysis for the identification of broad research links. Additionally, our dataset creation benefits from the study of past relevant mile-stones $[17,37,44,45]$ which allowed keyword analysis to consider qualitative and more re-strictive criteria. Therefore, the ABS list (2018) with its 1, 2, 3, 4 and $4^{*}$ ABS star classification was chosen as it has been widely adopted as a policy tool and researchers commonly use it for the identification of quality scientific articles [46-49].

Besides, the authors use more research's filter.

Our analysis is based on an emerging and continually evolving field of research, therefore we have focused on all sources in the database including not only peer-review articles but also conferences as a source of knowledge [50]. 
Moreover, the articles are selected from the business, management, and accounting fields due to the research questions strictly related to these three studied fields [51].

Finally, to increase the understandability and quality of publications, the authors considered only English language and peer-reviewed articles [17,20]. Therefore, all nonscientific sources such as non-peer-reviewed books, white papers and popular articles were not considered in our analysis.

Applying this previous restrictive research criteria, the authors selected 270 articles for further analysis. After the definition of the field of study considering the literature gap, the selection of the proper database, and the identification of the more restrictive research criteria, the authors began the analysis using Bibliometrix a statistical package available on R-Studio [52]. The software allowed us to retrieve relevant bibliometric qualitative and quantitative information such as authors, citations, country of production, or keywords. Figure 1 shows all the methodological flow followed by the authors.


Figure 1. Characteristics of the bibliometric study. Source: Author's elaboration.

\section{Results}

As previously mentioned, this bibliometric analysis started by describing the dataset characteristics (and related implications) of the 270 records. The scientific production re-search of a specific field is relevant for understanding the evolution of the literature, de-tecting research trends and organizing past research to suggest future research lines. Therefore, in the next paragraphs, we present primary research flow information, relevant sources, subject areas, authors data, social, thematic and intellectual structure.

\subsection{Main Information}

The identified articles covered a period ranging from 1986 to 2019. It is only from 2015 that publications started to become systematic; the number of publications also be-gan to be consistent and steadily grew (Figure 2).

The reason for this research intensification is related to the fact that in 2015 all United Nations Member States adopted the 2030 Agenda for Sustainable Development, with the 17 Sustainable Development Goals (SDGs) at its heart. Furthermore, since that year in a more pronounced way, states and the scientific world have focused more attention on 
sustainability in all its forms. This can also explain the rise to the peak of publications on sustainability. 


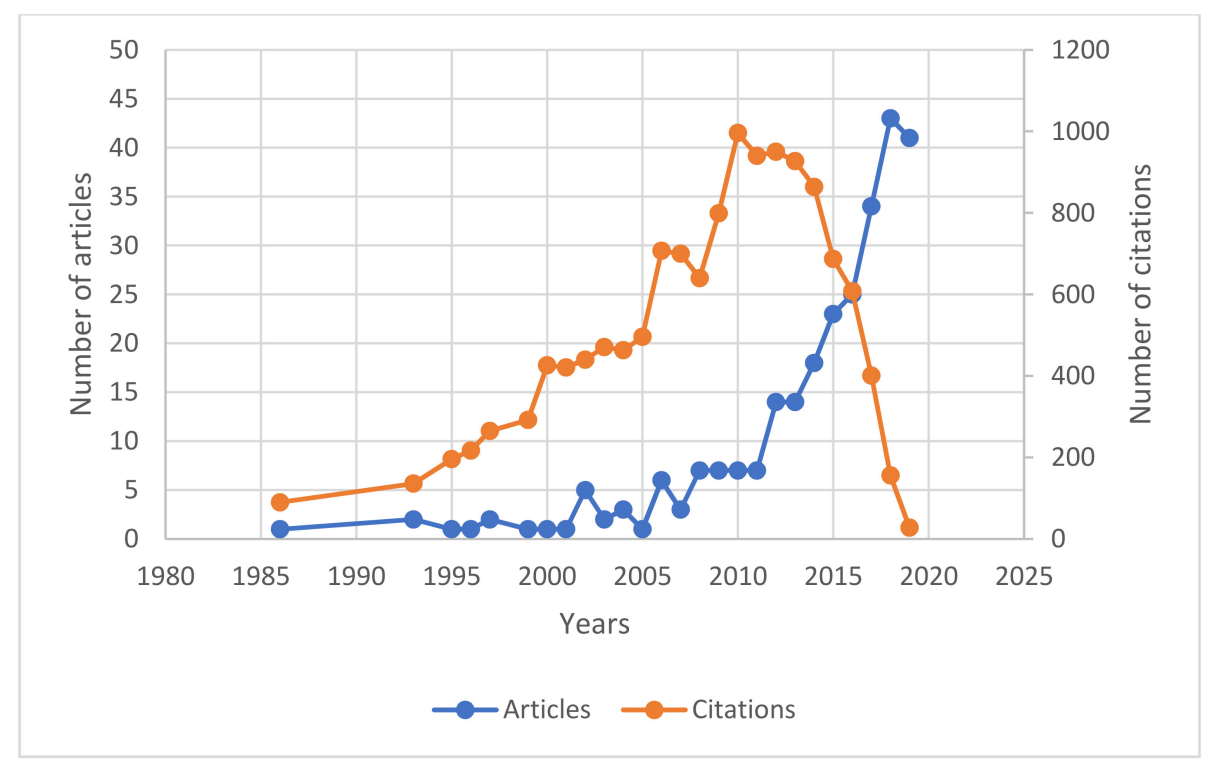

Figure 2. Distribution of publications and citations. Source: Authors' elaboration.

The data suggests that the topic has ancient origins. As can be seen, the quotations did not follow precisely the same trend as the publications-the citations up to 2010 were on the rise and reached over a thousand, after which there was a decrease. These findings suggest poor productivity in the early years. Table 1 indicates that researchers are aiming to solve this issue with a developing number of collaborations. In comparison, the number of publications and countries reporting on this issue has been gradually growing.

Table 1. Main information.

\begin{tabular}{|c|c|c|}
\hline Variables & Explanation & Results \\
\hline Timespan & Year of publication & 1986-2019 \\
\hline Sources (journals, books, etc.) & The frequency distribution of sources as journals & 19 \\
\hline Documents (articles) & Total number of documents & 270 \\
\hline Average years from publication & - & 5.96 \\
\hline Average citations per document & The average number of citations in each document & 19.19 \\
\hline Average citations per year per document & The average number of citations in each article & 2411 \\
\hline \multirow{2}{*}{ References } & Total number of references & 13.964 \\
\hline & DOCUMENT CONTENTS & \\
\hline Keywords plus (ID) & $\begin{array}{c}\text { Total number of phrases that frequently appear in the title } \\
\text { and on the article's references }\end{array}$ & 832 \\
\hline \multirow[t]{2}{*}{ Author's keywords (DE) } & Total number of keywords & 1.065 \\
\hline & AUTHORS & \\
\hline Authors & Total number of authors & 741 \\
\hline Author appearances & The authors' frequency distribution & 774 \\
\hline Authors of single-authored documents & The number of single authors per article & 43 \\
\hline \multirow[t]{2}{*}{ Authors of multi-authored documents } & The number of authors of multi-authored articles & 698 \\
\hline & AUTHORS COLLABORATION & \\
\hline Single-authored documents & - & 44 \\
\hline Documents per author & - & 0.364 \\
\hline Authors per document & - & 2.74 \\
\hline Co-Authors per documents & - & 2.87 \\
\hline Collaboration index & - & 3.09 \\
\hline
\end{tabular}

Source: Authors' elaboration. 


\subsection{Sources}

The top ten sources corresponded to more than half of the scientific production. Table 2 indicates a cumulative number of papers, with 40 articles and 649 citations, in the Journal of Cleaner Development. Furthermore, 23 articles and 618 quotes were included in the Journal of Business Ethics, listed second in the list. In turn, three journals with 10, 8 and 5 articles respectively (see Table 3), for sustainable entrepreneurship, were among the most quoted. They are Energy Policy, Ecological Economics and Tourism Management.

Table 2. Journal analysis.

\begin{tabular}{cccc}
\hline Journal & Number of Articles & H-Index & Citations \\
\hline Journal of Cleaner Production & 40 & 14 & 649 \\
Journal of Business Ethics & 23 & 13 & 618 \\
Physica A: Statistical Mechanics and its & 17 & 7 & 189 \\
Applications & 13 & 6 & 230 \\
Journal of Business Research & 11 & 4 & 35 \\
Journal of Social Entrepreneurship & 11 & 3 & 37 \\
Social Enterprise Journal & 11 & 6 & 143 \\
Technological Forecasting and Social Change & 10 & 6 & 371 \\
Energy Policy & 10 & 7 & 135 \\
Human Organization & 9 & 6 & 157 \\
\hline Computers in Human Behavior & &
\end{tabular}

Source: Authors' elaboration.

Table 3. The top 10 most productive authors.

\begin{tabular}{ccccccccc}
\hline Authors & A & C & C/A & 1st A & Last A & H-Index & Country & Affiliation \\
\hline Aseem & 3 & 28 & 9.33 & 2018 & 2019 & 11 & USA & University of Minnesota \\
Kaul & 3 & 28 & 9.33 & 2018 & 2019 & 9 & USA & University of Minnesota \\
Jiao Luo & 3 & 14 & 4.67 & 2015 & 2019 & 4 & Netherlands & $\begin{array}{c}\text { Maastricht University } \\
\text { Northwestern }\end{array}$ \\
Jarrod Ormiston & 3 & 26 & 8.67 & 2016 & 2016 & 8 & China & Polytechnical University \\
Jing Shao & 3 & 46 & 15.33 & 2017 & 2018 & 57 & Netherlands & University of Groningen \\
Frank Vanclay & 3 & 18 & 9.00 & 2016 & 2018 & 7 & Italy & Politecnico di Milano \\
Irene Bengo & 2 & 18 & 9.00 & 2016 & 2018 & 17 & Italy & Politecnico di Milano \\
Mario Calderini & 2 & 2013 & 2018 & 13 & Czech Republic & Charles University \\
Jana Dlouhà & 2 & 36 & 18.00 & 2013 & UK & The University of York \\
Bob Doherty & 2 & 2 & 1.00 & 2019 & 2019 & 29 & Australia & University of Queensland \\
Daniel M. Franks & 2 & 39 & 19.50 & 2012 & 2014 & 28 & Anita
\end{tabular}

A: Number of total articles; C: Number of citations for all papers; C/A: Average citation per article; 1st A: Year of first published article; Last A: Year of last published article. Source: Authors' elaboration.

\subsection{Subject Areas}

Figure 3 indicates the key topic areas for the online database on social finance and banking for science output. The figure demonstrates the multidisciplinary of the social finance and banking theme. The most relevant subject areas were Business with $16 \%$, followed by Environmental Sciences with 15\% and Engineering Environmental with 8\%.

The other subject category refers to Physics Multidisciplinary, Anthropology, Social Sciences Interdisciplinary, Energy, Fuels, Psychology Experimental, Psychology Multidisciplinary, Ecology, Geography, Development Studies, Hospitality Leisure Sport Tourism, Rehabilitation, Business Finance, Health Care Sciences Services, and Information Science Library Science. 


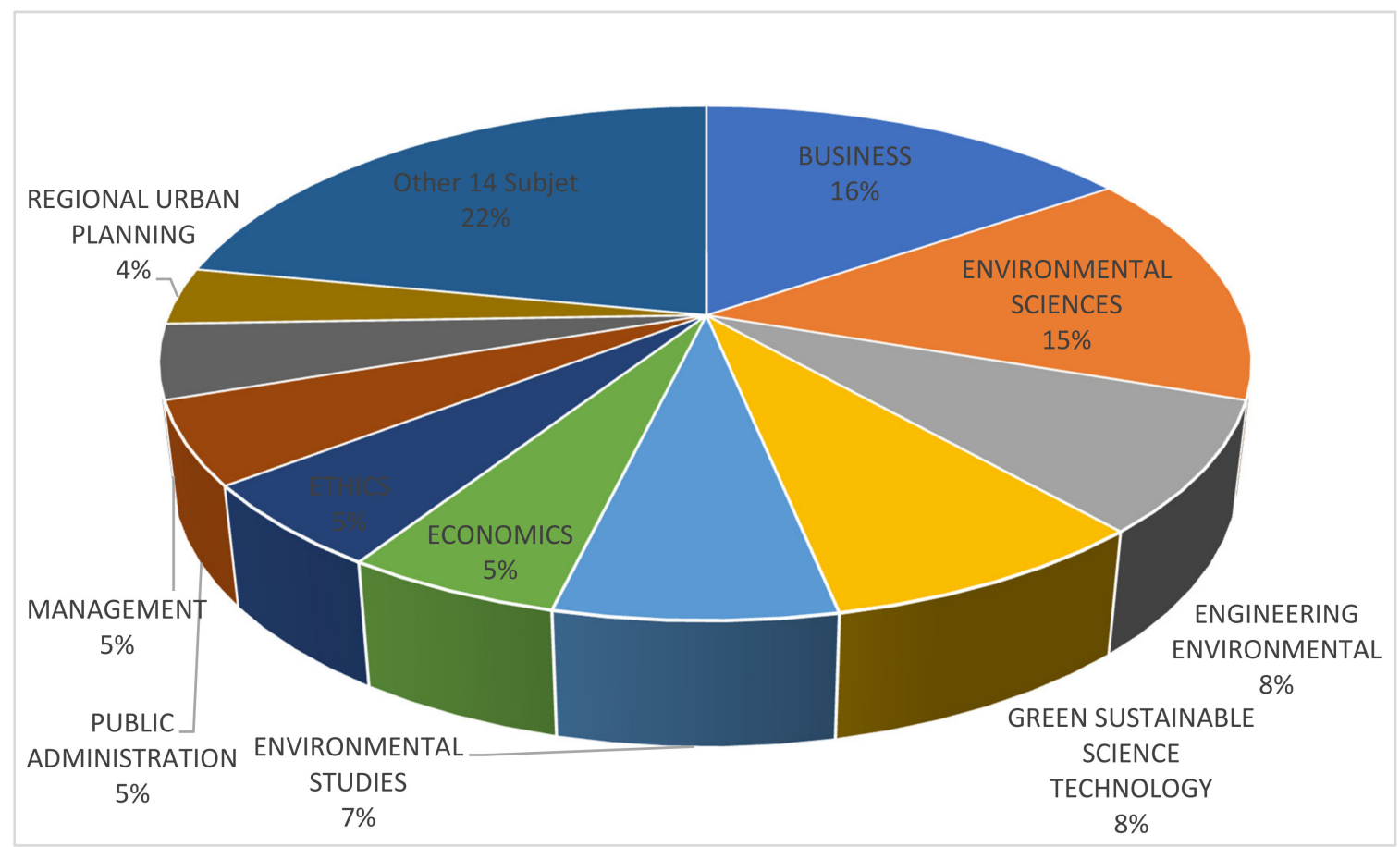

Figure 3. Subject areas that stand out in social finance and banking; Source: authors' elaboration based on Web of Science.

\subsection{Social Structure (Countries, Institutions, and Relevant Authors)}

As shown in Figure 4, several countries have published articles on social finance. However, most of the published articles were concentrated in a few countries. As expected, English-speaking countries (such as USA, UK and Australia) were the most represented. There was also a substantial presence of European countries. This may be due to the presence of a very developed financial/bank market [53,54].



Figure 4. Collaboration WorldMap. Source: author's elaboration with Bibliometrix R-Package.

The results of the collaboration were also reflected in the country of production; the first three countries confirmed to be those that natively speak English, the first in the 
USA with 79 papers, the UK with 65 papers and Australia with 56 papers. Then followed European countries, such as Spain with 44 papers and Italy with 35 papers. The results were also reflected in the affiliations, the most relevant with seven articles published were Texas A\&M University (however the citations amounted to only 11) and the University of Groningen, whose scientific production was cited 76 times. The third university in terms of production was the University of Sydney which published six papers, with the scientific output mentioned 99 times. As for the most cited affiliation, this was from the University of Washington, which published only two articles, but the paper Dyer et al. (2007) was the most mentioned of the sample analysed with 242 citations.

Considering the most productive authors, some useful insights have emerged from the bibliometric analysis. Although it has been verified that the theme had its roots already in the 1980s, there is no referenced author. Table 3 shows that the maximum number of articles written by these authors was five and three; also, five authors who wrote the articles: Aseem Kaul, Jiao Luo, Jarrod Ormiston, Jing Shao and Frank Vanclay. It turned out that the first two authors Aseem Kaul and Jiao Luo, collaborated on the same articles (which are Kaul \& Luo, 2018; Luo et al., 2018; and Luo \& Kaul, 2019). The same can also be seen for Irene Bengo and Mario Calderini who collaborated in writing the papers "Unlocking finance for social tech start-ups: Is there a new opportunity space?" and "New development: Are social impact bonds (SIBs) viable in Italy? A new roadmap" (Arena et al., 2018; Bengo \& Calderini, 2016). Among the authors analysed in this paper, only 23 had published two articles, while the remaining 713 had only published one article each. It appears that the first ten authors had published their scientific production only in the last eight years, so we cannot identify an author who has contributed to the development of the topic over the years.

\subsection{Conceptual Structure (Trends and Thematic Analysis)}

The conceptual and functional structure to analyse the research field and to identify and visualise its conceptual subdomains (i.e., topics/themes or general thematic areas) is also achieved by analyzing its thematic evolution [55]. These topics can be interpreted as textual knowledge conglomerates or as semantic/conceptual classes with various themes discussed in the field of study [56]. Therefore, this section includes an analysis of trend topics thematically related in this field and the topic dendrogram.

Figure 5 defines the trend topics, based on the Keywords Plus, which are words or phrases that often appeared in the titles of article references, but not in the title of the arti-cle itself. Based on an algorithm developed by Clarivate Analytics, Keywords Plus in-creases the search power of cited references by searching in all disciplines for all articles that have cited references in common. Since Keywords Plus terms are derived from the ti-tles of articles cited by the author of the article to be indexed, articles without references and articles whose references are not linked to the source articles will not have Keywords Plus. Keywords Plus may also be present for articles that do not have the author's key-words or may include important terms not listed among the author's keywords.

Garfield claimed that Keywords Plus terms could capture an article's content with greater accuracy and variety [57]. Keywords Plus is as powerful as Author Keywords in the bibliometric study of the information structure in science areas but is less detailed in the representation of the substance of the paper [58]. Table 4 highlights the whole number of Keywords Plus in the top 20 positions.

Figure 5 highlights that, in the analysed period, there was a change in the trend of the issues; in 2012 researchers focused their studies on strategy and quality of life, from 2014 to 2016 they focused on social impact and, recently, they focused on sustainability, entre-preneurship and the performance of the third sector. As can be seen from the figure un-derlying the study of the social impact, i.e., the study of the effect that the actions of a fi-nancial organization have on the community of reference [59], scholars began to develop this consistently from 2014 onwards. 


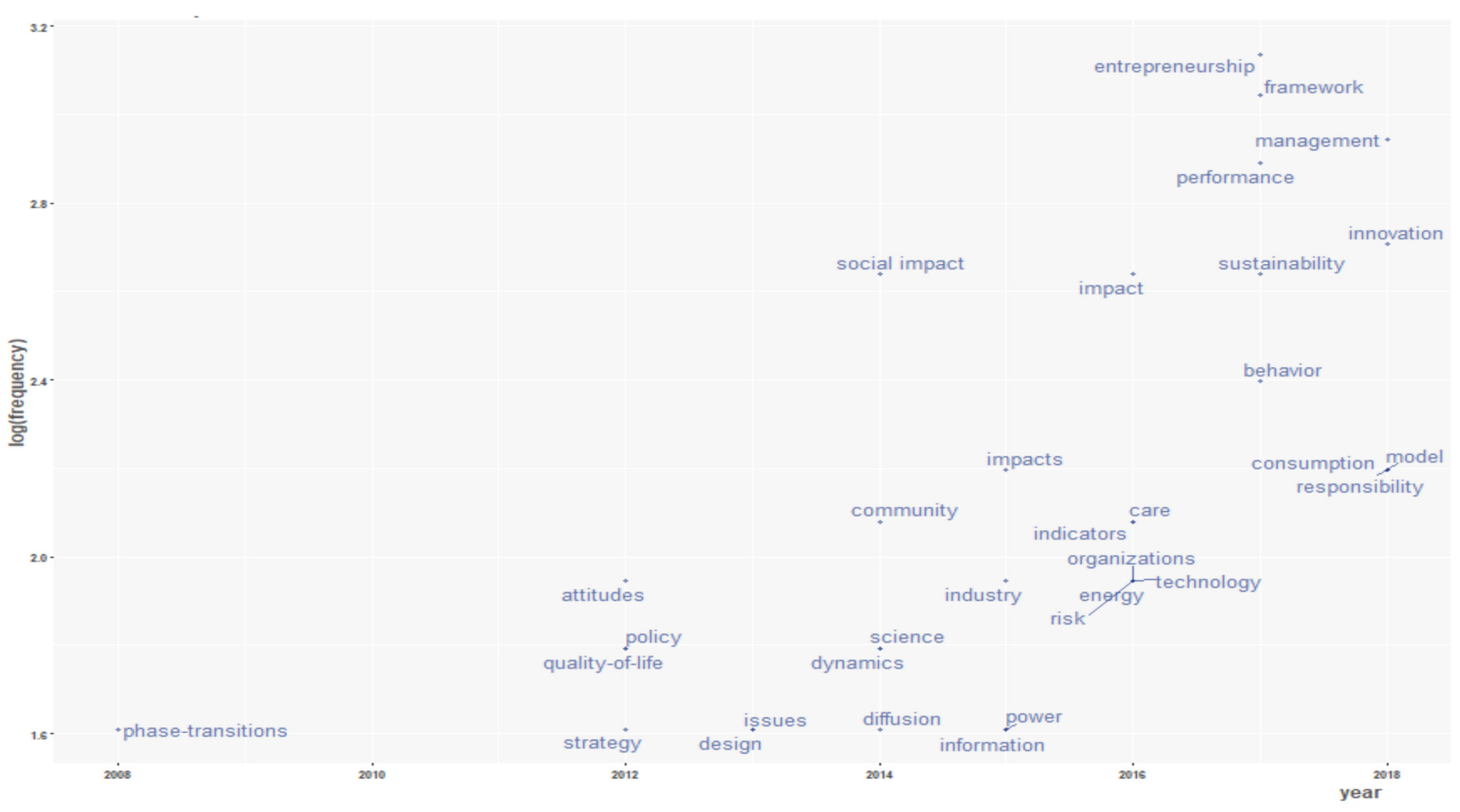

Figure 5. Trend topics. Source: Authors' elaboration.

Table 4. Journal analysis.

\begin{tabular}{cc}
\hline Keywords Plus (Top 20) & Articles \\
\hline Entrepreneurship & 23 \\
Framework & 21 \\
Management & 19 \\
Performance & 18 \\
Sustainability & 16 \\
Innovation & 15 \\
Impact & 14 \\
Social impact & 14 \\
Behavior & 12 \\
Governance & 10 \\
Model & 10 \\
Perceptions & 10 \\
Challenges & 9 \\
Consumption & 9 \\
Impacts & 9 \\
Responsibility & 9 \\
Business & 8 \\
Care & 8 \\
Community & 8 \\
Energy & 8 \\
\hline
\end{tabular}

Source: Authors' elaboration.

Figure 6 explains the composition of the academic sector at the conclusion of the study. The thematic map shows each keyword in the two-dimensional space explained by the axes [60]. The scale of the points is proportional to the cumulative input of each key-word. Through applying a clustering algorithm to a keyword network, it is possible to highlight the various themes of a given domain. Each cluster may be depicted on a special plot known as a strategic or thematic map. For example, centrality can be read as the im-portance of the theme in the whole field of science, and density can be read as a measure of the growth of the theme. Therefore, considering the figure, in this research flow as high-ly developed and isolated themes, authors found the risk and the perception among stakeholders of social banking and finance. As necessary and transversal themes, authors 
also found that performance of social finance was a highly repetitive theme. Moreover, considering the figure, the issue of sustainability is also acting as a "deus ex machina" towards this sector. Finally, as a declining theme, the following assistance was reported.

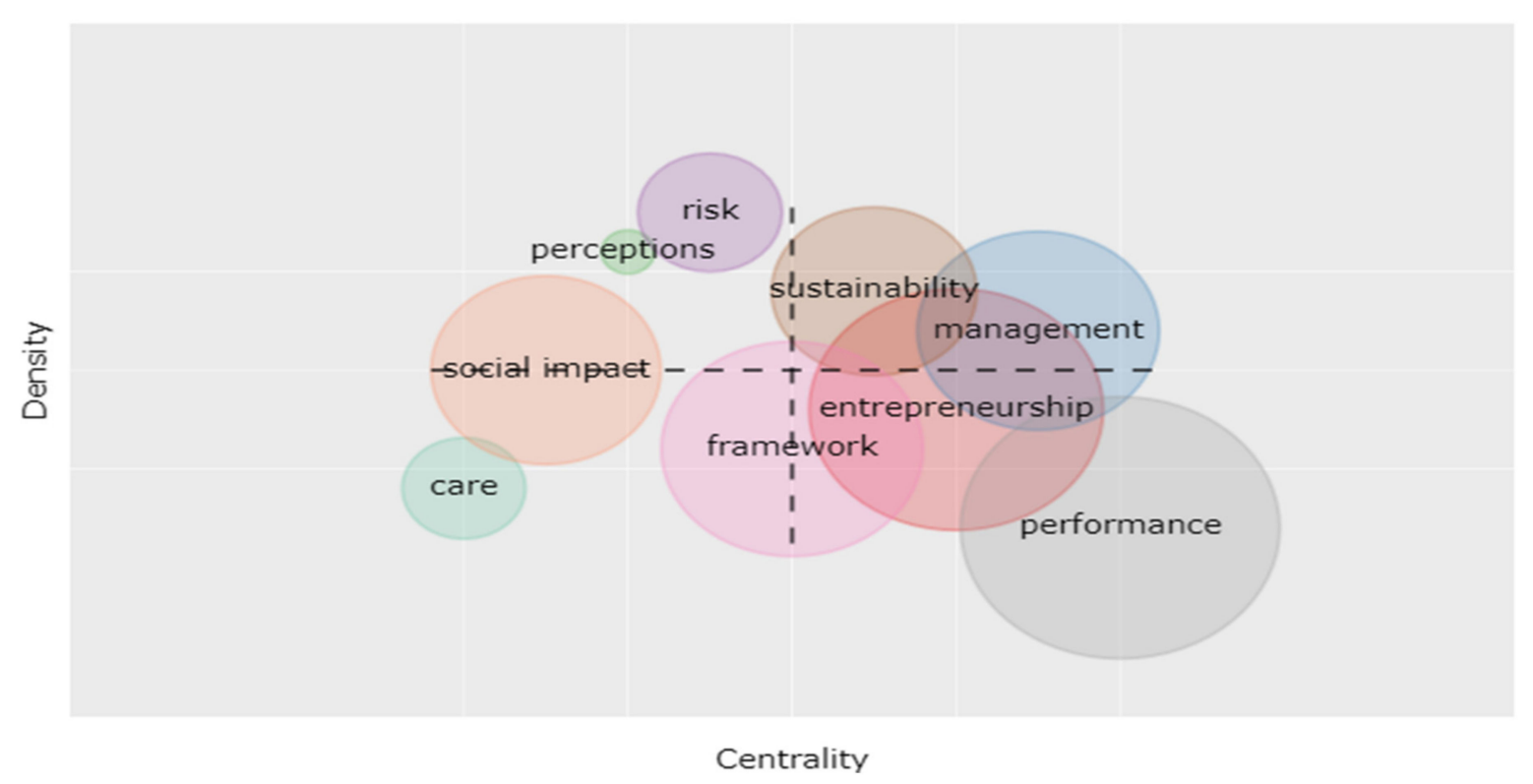

Figure 6. Thematic map in social finance and banking. Source: Authors' elaboration.

Authors often recognise problems that hold hybrid positions, i.e., they comprise two quadrants. For instance, the social impact theme occupied a position between emerging or declining themes and highly developed and isolated themes, which reflects the theoretical links about this topic. The need for a common framework occupying a position between emerging or declining themes and basic and transversal themes, and finally, entrepreneurship and management, occupied a position between motor themes and basic and transversal themes.

Figure 7 shows a dendrogram to observe the hierarchical relationship between keywords produced by hierarchical clustering [61]. The diagram shows two lines of analysis relating to the colours blue and red, respectively. It is used to assign objects to clusters by calculating the height of the various objects that are connected in the divisions. Humans are originally depicted in the dendrogram diagram by the researchers. The blue strand can be divided into four clusters, while the red strand consists of only one group. Each subdivision represents relevant themes and keywords. The results found that the flow of literature on social finance and banking included (1), peoples' well-being combined with technological innovation, (2) governance, (3) ethical investment and (4) corporate social responsibility (CSR). Finally, common to each of the above issues was the transparency (5) that the subject required. The combination of multi-disciplinary matters shows that social finance is an instrument aimed at improving peoples' well-being through entrepreneurial actions and projects. Moreover, the flow of re-search on social banking brings tools such as ethical investments and CSR vision to the previous literature. Also, the two themes at the theoretical approach level require greater transparency and consequently, governance of processes than the traditional financial system. 


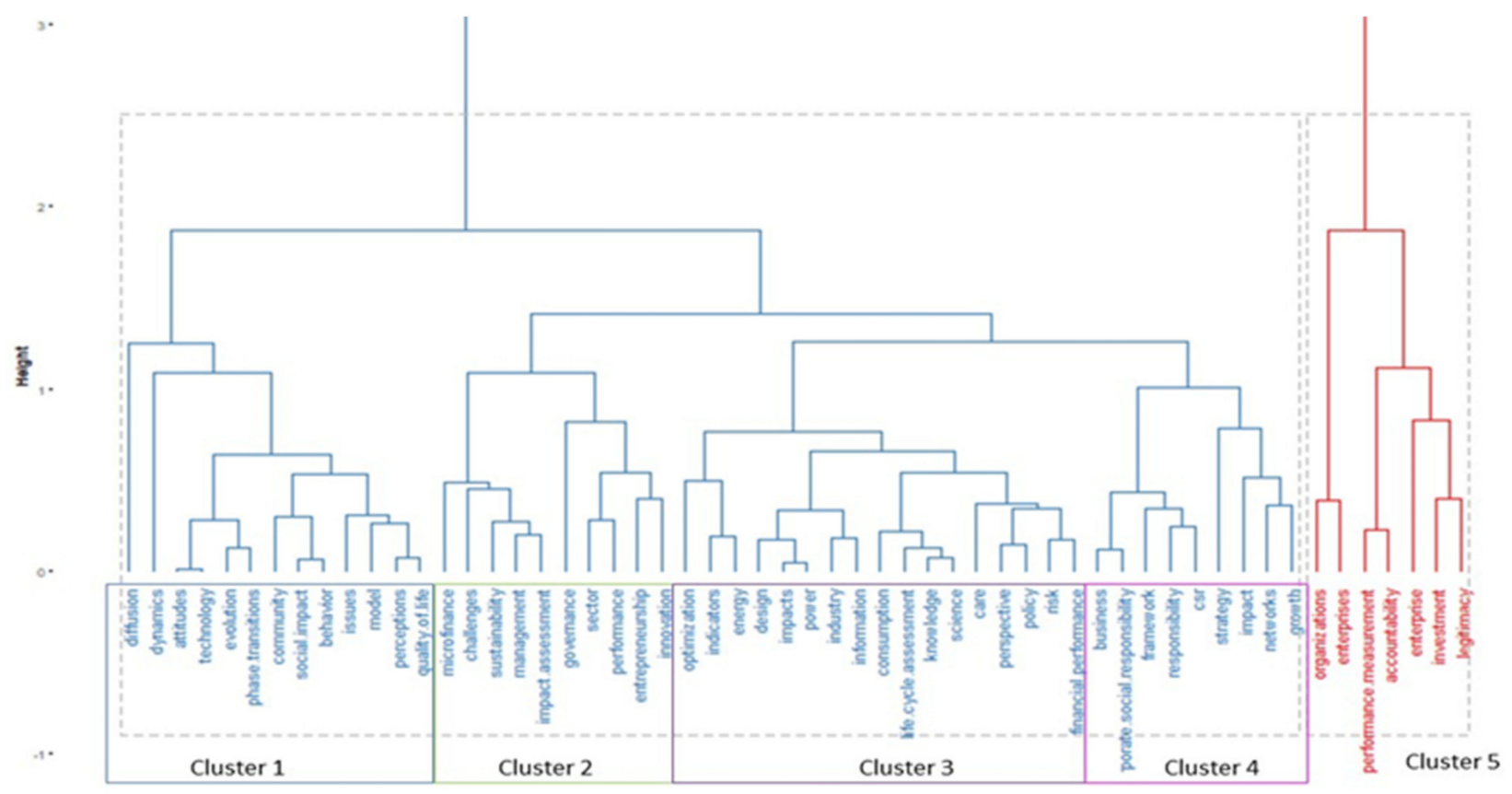

Figure 7. Topic dendrogram. Source: Authors' elaboration.

\subsection{Conceptual Structure (Trends and Thematic Analysis)}

The following paragraph aims outlines the results of co-citation analysis including historiographic parameters [44]. The author's co-citation analysis offers a variety of valuable perspectives to consider the effect of these scholars on the academic framework of the social finance and banking industry.

Figure 8 shows the social finance and banking impact co-citation analysis and the intellectual structure. The size of each cluster indicates the degree of co-citation of the authors, and the width of the lines shows the strength of the co-citation relations. The proximity between writers is seen by connections, not by spatial proximity to each other. Network edges can have varying meanings based on the citation type (co-citation or direct citation); citation analysis is the most common bibliometric analysis in the context of cocitation between authors or records. Co-citation research, as analysed over time, tends to discern a change in paradigms in schools of thought [62].

It is possible to classify three clusters from the following diagram.

Subgroups were identified in six teams of different colours: blue, purple, green, red, and orange. The brown sub-cluster was an outlier. The third orange cluster, composed of only two bi-univocal co-citations, was also defined as an outlier, for the distance from the centre of the co-citations. Above the centre of gravity, the first cluster was marked in blue, the theme of which can be described as theory and social structure. The purple cluster at the core of the study consisted of unique research on the effects of social finance and banking, comprised of specific studies. The green theme that formed around the purple theme and around the centre of gravity, was defined as the source of the focus of the study.

Moving on to historiographic analysis, it is possible to see chronological tables which highlight the most-cited works in and outside the collection. This is used to help scholars quickly identify the most significant work on this topic and trace its year-by-year historical development [63]. Historical path identifies a research topic and its core authors/documents, also, each node represents a document (included in the analysed collection) cited by other papers [64]. Each edge represents a direct citation. Nodes and edges were plotted on an oriented graph where the horizontal axis represents the publication years. Considering Figure 9, it is possible to identify three research paths, which were circled to make them easily identifiable. 


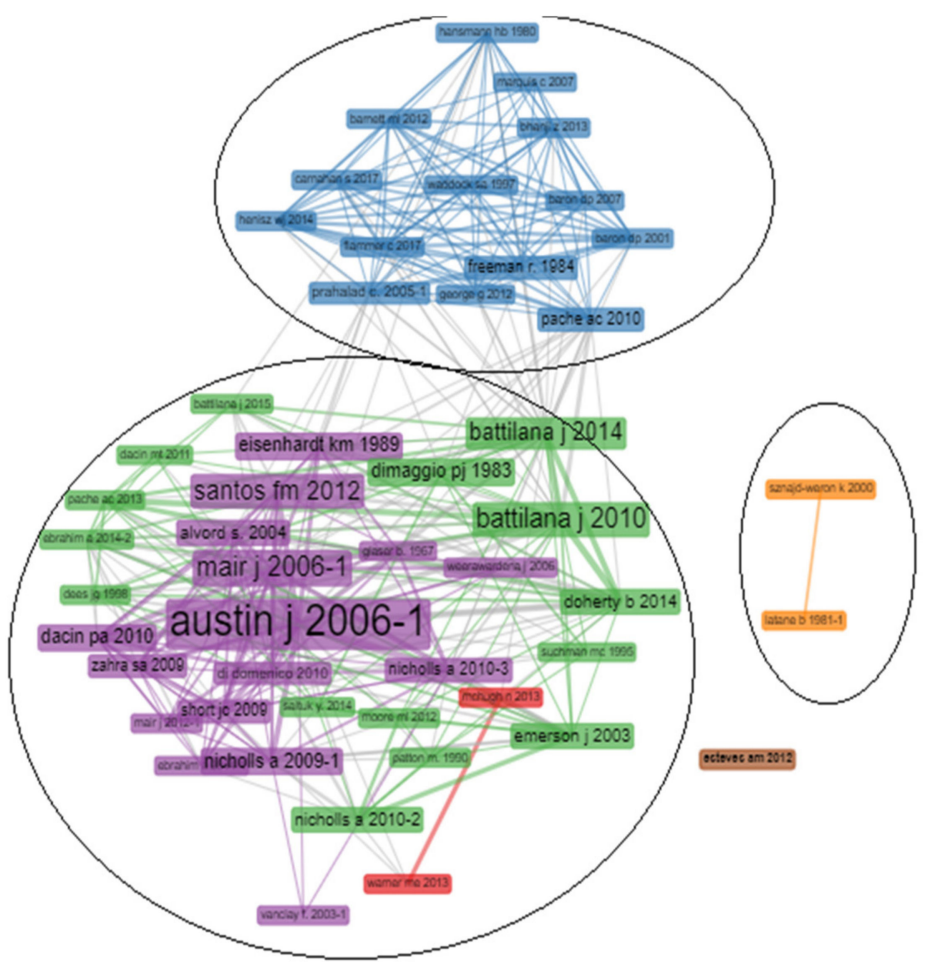

Figure 8. Co-citation analysis. Source: Authors' elaboration.

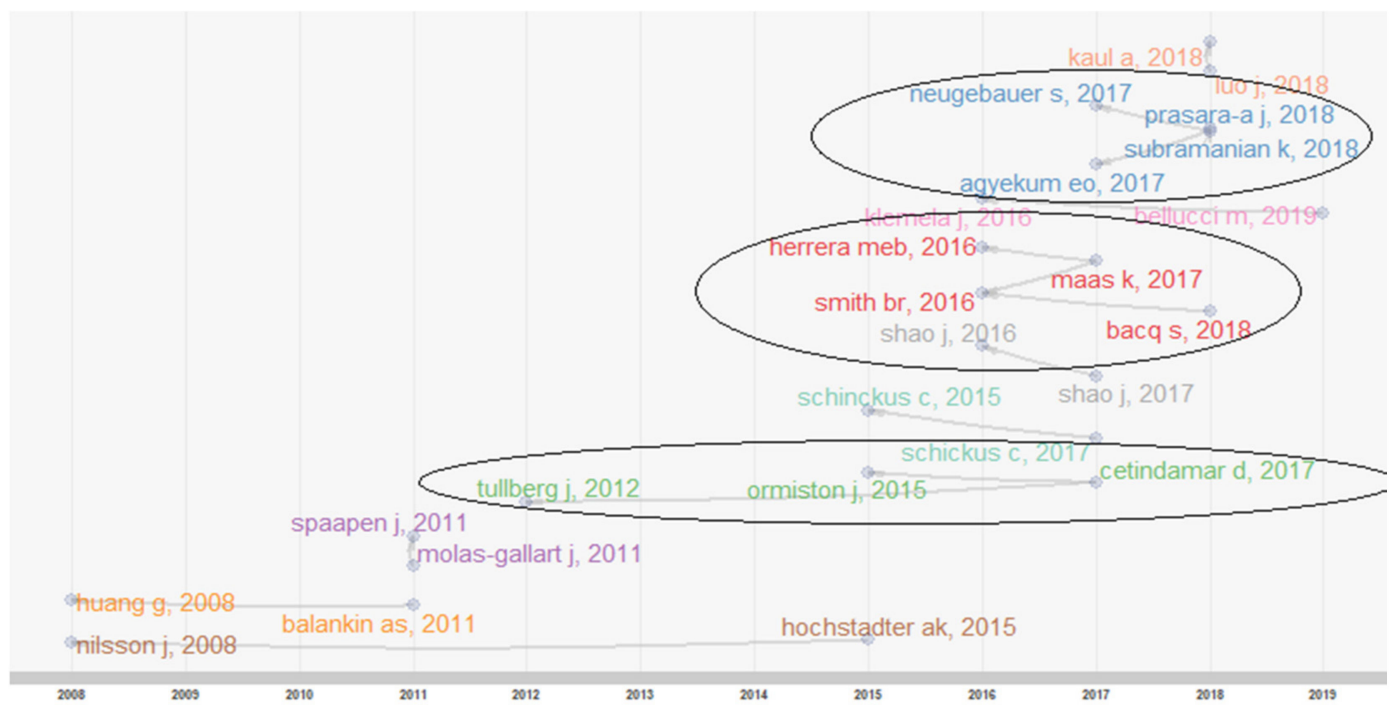

Figure 9. Historiographic parameters. Source: Authors' elaboration.

The first path is around the authors Cetindamar \& Ozkazanc-Pan (2017), Ormiston et al. (2015), and Tullberg (2012) [65-67]. The first path was identifiable with the knowledge of the structure, and the publications that traced the main foundations of the theme of finance and banking impact, investment impact and the development of this sector. The second path is around the authors Bacq \& Eddleston (2018), Herrera (2016), Maas \& Grieco (2017) and Smith et al. (2016) [68-71]), and is about social entrepreneurship and its role and impact on social challenges. And the third path is around the authors Agyekum et al. (2017), Neugebauer et al. (2017), Prasara-A \& Gheewala (2018) and Subramanian \& Yung (2018) [72-75], with publications about future social finance guidelines. 
The examined scientific production focused on the social issues of the community of reference concerning the standard of living and well-being of the same and the environmental impact assessment.

\section{Discussion}

Our bibliometric analysis focused on SF and SB research streams. The study aimed to investigate qualitative and quantitative variables such as authors, citations, journals and topics. Among them, some interesting insights emerged. For instance, Aseem Kau and Jiao Luo were the authors with the highest number of publications. Their contributions focused on corporate philanthropy as a form of reputation assurance; additionally, their work aimed to develop new theories for dealing with social issues. Other colleagues, such as Jarrod Ormiston, focused more on social impact investment as a social finance tool. Jing Shao focused mostly on sustainable development behaviour, seeing the link between social finance and the environment. Frank Vanclay recognised and addressed problems in implementing organizational human rights responsibility. Irene Bengo and Mario Calderini focused their scientific production on social impact bonds (SIBs) in Italy and financial tools that could be used to finance social innovation, with a particular emphasis on social technology start-ups that create and deliver technology-driven innovations to meet social challenges in a financially viable manner.

Additionally, our analysis shows that the journals with the highest number of articles on the topics were the Journal of Cleaner Production with 40 publications and the Journal of Business Ethics with 23 publications. Concerning the Journal of Cleaner Production, the publications referred to the link among sustainability, social impact and impact finance. At the same time, the Journal of Business Ethics considered ethical banking and social finance.

From the analysis conducted it was found that there was a consistent scientific production on ethical banking, finance impact and social impact, but only one paper was found to analyse what the social impact generated by the bank. Following the theories and historical processes of the bank's development in parallel with finance [4,76], it is undoubtedly of central interest to study the social impact it creates in ethical banking.

Keywords analysis on SF and SB revealed some important insights.

Cluster one related to peoples' well-being combined with technological innovation. The research strand confirmed the trend in the literature of collaboration between research centres to address and solve complex problems observed in the real world $[45,77,78]$. For instance, the paper of McCrea et al. [79] discussed community spirit and social investment in managing the development of new gas technology networks. Another topic was the analysis of the social impact of new fair wage models in the agricultural sector, showing how social impact assessment could be an essential decision-making tool for companies [73].

The second cluster related to governance, mainly concerning social impact. For example, as Luo e Kaul [80] discussed, efficient organisational forms are increasingly need-ed to address issues of social concern. The authors advocated the use of various governance instruments such as public-private partnerships as well as social enterprises. Ale-do-Tur and Domínguez-Gómez [81] also discussed this issue in order to stress how social impact assessment needs many tools from different fields, including governance.

The third cluster analysed referred to ethical investments.

Although at first glance, it could only refer to SB, the research area included a broad discussion. For example, the results of Schinckus [82] demonstrated how financial innovation in ethical investment (e.g., social bonds [83]) meets social impact by favouring funding for social projects such as rehabilitating prisoners rather than helping the homeless people. As authors, we believe that this paper is the academic and practical synthesis of how SF and SB can quickly meet. Finally, we also consider Revelli contribution [84] used a theoretical approach; it demonstrating how ethical and socially responsible investments require constant measurement of impact and extra-financial performance.

The fourth cluster concerned corporate social responsibility (CSR). Although it is a vast territory, the links between CSR, financial performance and social impact are many. 
For example, several authors showed that higher CSR had a positive value on companies' financial performance, on the social impact created towards stakeholders, and on the environmental impact of companies [85-87].

Finally, the last cluster included all the previous ones. Several authors emphasised that $\mathrm{SF}$ and $\mathrm{SB}$ research topics require greater transparency of information, especially about projects with a social and environmental purpose $[32,82,88]$.

\section{Conclusions}

To conclude, our study used science mapping workflow and multiple research questions to investigate the broad literature about social banking and finance yet unexplored. For accurately answering these research questions, we conducted a bibliometric analysis by using Bibliometrix R-package. Starting from the gap of the literature which saw two parallel literatures among the topics investigated [9], this paper provides an in-depth qualitative and quantitative analysis on bibliometric variables. Some useful theoretical in-sights can be made.

Firstly, scientific production in this area concerns social impact, social and sustainable finance and ethical banking. Therefore, as shown by Figure 6, banking and financial systems should engage and create useful tools for sustainable development, such as social and environmental projects, respectively [12].

Secondly, from a theoretical point of view, the analysis did not find parallel and competing issues. The research shows that social finance and social banking were not on different levels but instead that the banking approach provides practical tools to achieve more significant social impact for entrepreneurial choices. Therefore, we observed a union of the two pieces of literature and not a mere thematic division.

Thirdly, the keyword "social" does not only coincide with the aspect of caring for and fa-vouring others through social initiatives. The social element is linked to environmental good. For this reason, the topic has been widely studied by international journals such as Sustainability, which creates a tangible link considering sustainable development [89].

Moreover, our analysis also contained some practical insights.

Firstly, entrepreneurs and policymakers should aspire to and demand more transparency, as suggested by cluster five discovered in our article. The theoretical link between the topics discussed, has practical insights in terms of reporting. The social approach requires more transparency, and the social finance and banking sector needs to provide more answers in terms of writing. Therefore, more practical accountability may be required to include both social and environmental impact assessment methodologies created for funded activities.

Secondly, the contributions and critical words in this research flow call for multistakeholder and multidisciplinary governance that encourages social enterprises to convey their role as protagonists. Therefore, policymakers will be able to benefit from the analysis by noting how collaboration is valued at a scientific level and could enhance social entrepreneurship initiatives for the good of the community and the environment.

Our article opens exciting scenarios for future research.

The analysis shows the beginning of research in new technologies. Future studies could be conducted on blockchain technology and the ability to track investments within social finance. Furthermore, case studies could investigate the role of trust in sustainable investments, transparency, and decentralisation. Moreover, an interesting point for future research could be the way to deal with cryptocurrency transactions, which will most likely lead to a higher trust in the social finance sector activities attracting a higher number of donors or investors and benefiting the under-privileged communities.

Further studies should also be conducted to understand whether social and environmental impact assessments could be a tool to stimulate social finance initiatives. More in-depth studies could also be achieved in terms of the social impact created by the banking system. Researchers could verify the level of responsibility of financial institutions in solving social, ethical and environmental problems. Furthermore, the research should 
focus on comparing academic perspectives of this research flow from our contribution, assessing the demands of professionals.

Finally, like all research, our study has limitations.

Firstly, to ensure a rigorous methodology, we have limited the articles within the sample. This may have caused us to lose interesting publications and proceedings for research. Secondly, considering the analysis of bibliometric variables, future studies could dwell on broader samples of literature also finalising investigations with open codes for better identification of the scientific topics discussed.

Author Contributions: Conceptualization, S.S.; methodology, F.C. and D.P.; software, F.C. and D.P.; validation, D.C.; formal analysis, S.S. and D.C.; investigation, D.C.; data curation, F.C. and D.P.; writing-original draft preparation, F.C. and D.P.; writing-review and editing, D.C.; visualization, D.C., D.P., F.C.; supervision, S.S. All authors have read and agreed to the published version of the manuscript.

Funding: This research received no external funding.

Institutional Review Board Statement: Not applicable.

Informed Consent Statement: Not applicable.

Data Availability Statement: The data are available on request; however, it is possible to extract the bibliometric source directly from the databased used by the authors.

Conflicts of Interest: The authors declare no conflict of interest.

\section{References}

1. Bishop, M.; Green, M. Philanthrocapitalism: How Giving Can Save the World; Bloomsbury Publishing: New York, NY, USA, 2010.

2. Emerson, J.; Spitzer, J. From Fragmentation to Function: Critical Concepts and Writing on Social Capital Markets' Structure, Operation and Innovation; University of Oxford: Oxford, UK, 2007.

3. Nicholls, A. The Legitimacy of Social Entrepreneurship: Reflexive Isomorphism in a Pre-Paradigmatic Field. Entrep. Theory Pract. 2010, 34, 611-633. [CrossRef]

4. Weber, O.; Duan, Y. Social Finance and Banking. In Socially Responsible Finance and Investing: Financial Institutions, Corporations, Investors, and Activists; John Wiley \& Sons: Hoboken, NJ, USA, 2012; Volume 160, p. 180.

5. Périlleux, A. When Social Enterprises Engage in Finance: Agents of Change in Lending Relationships, a Belgian Typology. Strateg. Chang. 2015, 24, 285-300. [CrossRef]

6. Allison, T.H.; Davis, B.C.; Short, J.C.; Webb, J.W. Crowdfunding in a Prosocial Microlending Environment: Examining the Role of Intrinsic versus Extrinsic Cues. Entrep. Theory Pract. 2015, 39, 53-73. [CrossRef]

7. Howard, E. Challenges and Opportunities in Social Finance in the UK.; Cicero Group: Washington, DC, USA, 2012.

8. Martínez-Gómez, C.; Jiménez-Jiménez, F.; Alba-Fernández, M.V. Determinants of Overfunding in Equity Crowdfunding: An Empirical Study in the UK and Spain. Sustainability 2020, 12, 10054. [CrossRef]

9. Rizzi, F.; Pellegrini, C.; Battaglia, M. The Structuring of Social Finance: Emerging Approaches for Supporting Environmentally and Socially Impactful Projects. J. Clean. Prod. 2018, 170, 805-817. [CrossRef]

10. De Clerck, F. Ethical banking. In Ethical Prospects; Springer: Berlin/Heidelberg, Germany, 2009; pp. $209-227$.

11. Weber, O.; Remer, S. Social Banks and the Future of Sustainable Finance; Taylor \& Francis: Oxfordshire, UK, 2011 ; Volume 64.

12. Baraibar-Diez, E.; Luna, M.; Odriozola, M.D.; Llorente, I. Mapping Social Impact: A Bibliometric Analysis. Sustainability 2020, 12, 9389. [CrossRef]

13. Höhnke, N. Doing Good or Avoiding Evil? An Explorative Study of Depositors' Reasons for Choosing Social Banks in the Pre and Post Crisis Eras. Sustainability 2020, 12, 10082. [CrossRef]

14. Rizzello, A.; Kabli, A. Sustainable Financial Partnerships for the SDGs: The Case of Social Impact Bonds. Sustainability 2020, 12, 5362. [CrossRef]

15. Dal Mas, F.; Massaro, M.; Lombardi, R.; Garlatti, A. From Output to Outcome Measures in the Public Sector: A Structured Literature Review. Int. J. Organ. Anal. 2019, 27, 1631-1656. [CrossRef]

16. Dumay, J.; Cai, L. A Review and Critique of Content Analysis as a Methodology for Inquiring into IC Disclosure. J. Intellect. Cap. 2014, 15, 264-290. [CrossRef]

17. Massaro, M.; Dumay, J.; Guthrie, J. On the Shoulders of Giants: Undertaking a Structured Literature Review in Accounting. Account. Audit. Account. J. 2016, 29,767-801. [CrossRef]

18. Massaro, M.; Dumay, J.; Garlatti, A.; Dal Mas, F. Practitioners' Views on Intellectual Capital and Sustainability: From a Performance-Based to a Worth-Based Perspective. J. Intellect. Cap. 2018, 19, 367-386. [CrossRef]

19. Secinaro, S.; Brescia, V.; Calandra, D.; Biancone, P. Employing Bibliometric Analysis to Identify Suitable Business Models for Electric Cars. J. Clean. Prod. 2020, 264, 121503. [CrossRef] 
20. Secinaro, S.; Calandra, D. Halal Food: Structured Literature Review and Research Agenda. Br. Food J. 2020. ahead-of-print. [CrossRef]

21. Rangan, V.K.; Appleby, S.; Moon, L. The Promise of Impact Investing; Background Note; Harvard Business School: Boston, MA, USA, 2011.

22. Eurosif Impact Investing in Europe: Extract from European SRI Study 2014. European Sustainable Investment Forum, Brussel. Available online: https://informaconnect.com/sustainability-and-impact-investor-forum/?vip_code=FKN274 2GOOGLE\&gclid=Cj0KCQjw7qn1BRDqARIsAKMbHDaP7nZqySPzBzxA_RJDzCAt4JJ8vTBCODDpIH_IL20WG_0AN6sv1 CoaAiZEEALw_wcB (accessed on 30 April 2020).

23. Baumli, K.; Jamasb, T. Assessing Private Investment in African Renewable Energy Infrastructure: A Multi-Criteria Decision Analysis Approach. Sustainability 2020, 12, 9425. [CrossRef]

24. Di Domenico, M.; Haugh, H.; Tracey, P. Social Bricolage: Theorizing Social Value Creation in Social Enterprises. Entrep. Theory Pract. 2010, 34, 681-703. [CrossRef]

25. Gundry, L.K.; Kickul, J.R.; Griffiths, M.D.; Bacq, S.C. Creating Social Change out of Nothing: The Role of Entrepreneurial Bricolage in Social Entrepreneurs' Catalytic Innovations. Adv. Entrep. Firm Emerg. Growth 2011, 13, 1-24.

26. Huybrechts, B.; Nicholls, A. Social entrepreneurship: Definitions, drivers and challenges. In Social Entrepreneurship and Social Business; Springer: Berlin/Heidelberg, Germany, 2012; pp. 31-48.

27. Urmanaviciene, A.; Arachchi, U.S. The Effective Methods and Practices for Accelerating Social Entrepreneurship through Corporate Social Responsibility. Eur. J. Soc. Impact Circ. Econ. 2020, 1, 27-47. [CrossRef]

28. Martin, M.; Impact Economy. Status of the Social Impact Investing Market: A Primer. 2013. Available online: https://www. impacteconomy.com/papers/IE_PRIMER_JUNE2013_EN (accessed on 10 November 2020).

29. Barigozzi, F.; Tedeschi, P. Credit Markets with Ethical Banks and Motivated Borrowers. Rev. Financ. 2015, 19, 1281-1313. [CrossRef]

30. Nicholls, A. The Institutionalization of Social Investment: The Interplay of Investment Logics and Investor Rationalities. J. Soc. Entrep. 2010, 1, 70-100. [CrossRef]

31. Secinaro, S.; Corvo, L.; Brescia, V.; Iannaci, D. Hybrid Organizations: A Systematic Review of the Current Literature. Int. Bus. Res. 2019, 12, p1. [CrossRef]

32. Iannaci, D. Reporting Tools for Social Enterprises: Between Impact Measurement and Stakeholder Needs. Eur. J. Soc. Impact Circ. Econ. 2020, 1, 1-18. [CrossRef]

33. Bugg-Levine, A.; Emerson, J. Impact Investing: Transforming How We Make Money While Making a Difference. Innov. Technol. Gov. Glob. 2011, 6, 9-18. [CrossRef]

34. Hebb, T. Impact Investing and Responsible Investing: What Does It Mean? Taylor \& Francis: Oxfordshire, UK, 2013.

35. Glänzel, G.; Scheuerle, T. Social Impact Investing in Germany: Current Impediments from Investors' and Social Entrepreneurs' Perspectives. Volunt. Int. J. Volunt. Nonprofit Organ. 2016, 27, 1638-1668. [CrossRef]

36. Dionisio, M. The Evolution of Social Entrepreneurship Research: A Bibliometric Analysis. Soc. Enterp. J. 2019, 15, 22-45. [CrossRef]

37. Biancone, P.P.; Saiti, B.; Petricean, D.; Chmet, F. The Bibliometric Analysis of Islamic Banking and Finance. J. Islamic Account. Bus. Res. 2020. ahead-of-print. [CrossRef]

38. Fabregat-Aibar, L.; Barberà-Mariné, M.G.; Terceño, A.; Pié, L. A Bibliometric and Visualization Analysis of Socially Responsible Funds. Sustainability 2019, 11, 2526. [CrossRef]

39. Okoli, C.; Schabram, K. A Guide to Conducting a Systematic Literature Review of Information Systems Research. SSRN Electron. J. 2010. [CrossRef]

40. Neely, A. The Evolution of Performance Measurement Research. Int. J. Oper. Prod. Manag. 2005, 25, 1264-1277. [CrossRef]

41. Riva, P.; Comoli, M.; Bavagnoli, F.; Gelmini, L. Performance Measurement: From Internal Management to External Disclosure. Corp. Ownersh. Control 2015, 13, 907-926. [CrossRef]

42. Taticchi, P.; Tonelli, F.; Cagnazzo, L. Performance Measurement and Management: A Literature Review and a Research Agenda. Meas. Bus. Excell. 2010, 14, 4-8. [CrossRef]

43. Chen, G.; Xiao, L. Selecting Publication Keywords for Domain Analysis in Bibliometrics: A Comparison of Three Methods. J. Informetr. 2016, 10, 212-223. [CrossRef]

44. Dal Mas, F.; Garcia-Perez, A.; José Sousa, M.; Lopes da Costa, R.; Cobianchi, L. Knowledge Translation in the Healthcare Sector, A Structured Literature Review. Electron. J. Knowl. Manag. 2020, 18.

45. Massaro, M.; Secinaro, S.; Mas, F.D.; Brescia, V.; Calandra, D. Industry 4.0 and Circular Economy: An Exploratory Analysis of Academic and Practitioners' Perspectives. Bus. Strategy Environ. 2020. [CrossRef]

46. Li, J.; Wu, D.; Li, J.; Li, M. A Comparison of 17 Article-Level Bibliometric Indicators of Institutional Research Productivity: Evidence from the Information Management Literature of China. Inf. Process. Manag. 2017, 53, 1156-1170. [CrossRef]

47. Mingers, J.; Willmott, H. Taylorizing Business School Research: On the 'One Best Way' Performative Effects of Journal Ranking Lists. Hum. Relat. 2013, 66, 1051-1073. [CrossRef]

48. Tüselmann, H.; Sinkovics, R.R.; Pishchulov, G. Revisiting the Standing of International Business Journals in the Competitive Landscape. J. World Bus. 2016, 51, 487-498. [CrossRef] 
49. Xu, X.; Chen, X.; Jia, F.; Brown, S.; Gong, Y.; Xu, Y. Supply Chain Finance: A Systematic Literature Review and Bibliometric Analysis. Int. J. Prod. Econ. 2018, 204, 160-173. [CrossRef]

50. Easterby-Smith, M.; Thorpe, R.; Jackson, P.; Lowe, A. Management Research, 4th ed.; SAGE: London, UK, 2012.

51. Levy, Y.; Ellis, T.J. A Systems Approach to Conduct an Effective Literature Review in Support of Information Systems Research. Inf. Sci. Int. J. Emerg. Transdiscipl. 2006, 9, 181-212. [CrossRef]

52. Aria, M.; Cuccurullo, C. Bibliometrix: An R-Tool for Comprehensive Science Mapping Analysis. J. Informetr. 2017, 11, 959-975. [CrossRef]

53. Fry, M.J. Money and Capital or Financial Deepening in Economic Developments. In Money and Monetary Policy in Less Developed Countries; Elsevier: Amsterdam, The Netherlands, 1980; pp. 107-113.

54. Galbis, V. Financial Intermediation and Economic Growth in Less-Developed Countries: A Theoretical Approach. J. Dev. Stud. 1977, 13, 58-72. [CrossRef]

55. Cobo, M.J.; López-Herrera, A.G.; Herrera-Viedma, E.; Herrera, F. An Approach for Detecting, Quantifying, and Visualizing the Evolution of a Research Field: A Practical Application to the Fuzzy Sets Theory Field. J. Informetr. 2011, 5, 146-166. [CrossRef]

56. Aparicio, G.; Iturralde, T.; Maseda, A. Conceptual Structure and Perspectives on Entrepreneurship Education Research: A Bibliometric Review. Eur. Res. Manag. Bus. Econ. 2019, 25, 105-113. [CrossRef]

57. Garfield, E.; Sher, I.H. Key Words plus [TM]-Algorithmic Derivative Indexing. J. Am. Soc. Inf. Sci. 1993, 44, 298-299. [CrossRef]

58. Zhang, J.; Yu, Q.; Zheng, F.; Long, C.; Lu, Z.; Duan, Z. Comparing Keywords plus of WOS and Author Keywords: A Case Study of Patient Adherence Research. J. Assoc. Inf. Sci. Technol. 2016, 67, 967-972. [CrossRef]

59. Latané, B. The Psychology of Social Impact. Am. Psychol. 1981, 36, 343. [CrossRef]

60. Noyons, E. Bibliometric Mapping of Science in a Policy Context. Scientometrics 2004, 50, 83-98. [CrossRef]

61. Forina, M.; Armanino, C.; Raggio, V. Clustering with Dendrograms on Interpretation Variables. Anal. Chim. Acta 2002, 454, 13-19. [CrossRef]

62. Small, H. Co-Citation in the Scientific Literature: A New Measure of the Relationship between Two Documents. J. Am. Soc. Inf. Sci. 1973, 24, 265-269. [CrossRef]

63. Vogel, B.; Reichard, R.J.; Batistič, S.; Černe, M. A Bibliometric Review of the Leadership Development Field: How We Got Here, Where We Are, and Where We Are Headed. Leadersh. Q. 2020, 101381. [CrossRef]

64. Garfield, E. Historiographic Mapping of Knowledge Domains Literature. J. Inf. Sci. 2004, 30, 119-145. [CrossRef]

65. Cetindamar, D.; Ozkazanc-Pan, B. Assessing Mission Drift at Venture Capital Impact Investors. Bus. Ethics A Eur. Rev. 2017, 26, 257-270. [CrossRef]

66. Ormiston, J.; Charlton, K.; Donald, M.S.; Seymour, R.G. Overcoming the Challenges of Impact Investing: Insights from Leading Investors. J. Soc. Entrep. 2015, 6, 352-378. [CrossRef]

67. Tullberg, J. Triple Bottom Line-A Vaulting Ambition? Bus. Ethics A Eur. Rev. 2012, 21, 310-324. [CrossRef]

68. Bacq, S.; Eddleston, K.A. A Resource-Based View of Social Entrepreneurship: How Stewardship Culture Benefits Scale of Social Impact. J. Bus. Ethics 2018, 152, 589-611. [CrossRef]

69. Herrera, M.E.B. Innovation for Impact: Business Innovation for Inclusive Growth. J. Bus. Res. 2016, 69, 1725-1730. [CrossRef]

70. Maas, K.; Grieco, C. Distinguishing Game Changers from Boastful Charlatans: Which Social Enterprises Measure Their Impact? J. Soc. Entrep. 2017, 8, 110-128. [CrossRef]

71. Smith, B.R.; Kistruck, G.M.; Cannatelli, B. The Impact of Moral Intensity and Desire for Control on Scaling Decisions in Social Entrepreneurship. J. Bus. Ethics 2016, 133, 677-689. [CrossRef]

72. Agyekum, E.O.; Fortuin, K.K.; van der Harst, E. Environmental and Social Life Cycle Assessment of Bamboo Bicycle Frames Made in Ghana. J. Clean. Prod. 2017, 143, 1069-1080. [CrossRef]

73. Neugebauer, S.; Emara, Y.; Hellerström, C.; Finkbeiner, M. Calculation of Fair Wage Potentials along Products' Life CycleIntroduction of a New Midpoint Impact Category for Social Life Cycle Assessment. J. Clean. Prod. 2017, 143, 1221-1232. [CrossRef]

74. Prasara-A, J.; Gheewala, S.H. Applying Social Life Cycle Assessment in the Thai Sugar Industry: Challenges from the Field. J. Clean. Prod. 2018, 172, 335-346. [CrossRef]

75. Subramanian, K.; Yung, W.K. Modeling Social Life Cycle Assessment Framework for an Electronic Screen Product-A Case Study of an Integrated Desktop Computer. J. Clean. Prod. 2018, 197, 417-434. [CrossRef]

76. Jeucken, M. Sustainable Finance and Banking: The Financial Sector and the Future of the Planet; Earthscan: London, UK, 2010.

77. Zuo, Z.; Zhao, K. The More Multidisciplinary the Better-The Prevalence and Interdisciplinarity of Research Collaborations in Multidisciplinary Institutions. J. Informetr. 2018, 12, 736-756. [CrossRef]

78. Klemeš, J.J.; Varbanov, P.S.; Huisingh, D. Recent Cleaner Production Advances in Process Monitoring and Optimisation. J. Clean. Prod. 2012, 34, 1-8. [CrossRef]

79. McCrea, R.; Walton, A.; Leonard, R. Rural Communities and Unconventional Gas Development: What's Important for Maintaining Subjective Community Wellbeing and Resilience over Time? J. Rural Stud. 2019, 68, 87-99. [CrossRef]

80. Luo, J.; Kaul, A. Private Action in Public Interest: The Comparative Governance of Social Issues. Strateg. Manag. J. 2019, 40, 476-502. [CrossRef]

81. Aledo-Tur, A.; Domínguez-Gómez, J.A. Social Impact Assessment (SIA) from a Multidimensional Paradigmatic Perspective: Challenges and Opportunities. J. Environ. Manag. 2017, 195, 56-61. [CrossRef] 
82. Schinckus, C. Financial Innovation as a Potential Force for a Positive Social Change: The Challenging Future of Social Impact Bonds. Res. Int. Bus. Financ. 2017, 39, 727-736. [CrossRef]

83. Arena, M.; Bengo, I.; Calderini, M.; Chiodo, V. Social Impact Bonds: Blockbuster or Flash in a Pan? Int. J. Public Adm. 2016, 39 , 927-939. [CrossRef]

84. Revelli, C. Re-Embedding Financial Stakes within Ethical and Social Values in Socially Responsible Investing (SRI). Res. Int. Bus. Financ. 2016, 38, 1-5. [CrossRef]

85. Shen, C.-H.; Chang, Y. Ambition Versus Conscience, Does Corporate Social Responsibility Pay off? The Application of Matching Methods. J. Bus. Ethics 2009, 88, 133-153. [CrossRef]

86. Campra, M.; Esposito, P.; Lombardi, R. The Engagement of Stakeholders in Nonfinancial Reporting: New Information-Pressure, Stimuli, Inertia, under Short-Termism in the Banking Industry. Corp. Soc. Responsib. Environ. Manag. 2020, 27, 1436-1444. [CrossRef]

87. Davila, A.; Rodriguez-Lluesma, C.; Elvira, M.M. Engaging Stakeholders in Emerging Economies: The Case of Multilatinas. J. Bus. Ethics 2018, 152, 949-964. [CrossRef]

88. Haggerty, J.; McBride, K. Does Local Monitoring Empower Fracking Host Communities? A Case Study from the Gas Fields of Wyoming. J. Rural Stud. 2016, 43, 235-247. [CrossRef]

89. Muñoz de Prat, J.; Escriva-Beltran, M.; Gómez-Calvet, R. Joint Ventures and Sustainable Development. A Bibliometric Analysis. Sustainability 2020, 12, 10176. [CrossRef] 